(C) 2021, The Authors. Published by Elsevier Inc. and Fass Inc. on behalf of the American Dairy Science Association ${ }^{\circledR}$. This is an open access article under the CC BY-NC-ND license (http://creativecommons.org/licenses/by-nc-nd/4.0/).

\title{
Omasal flow of nonstructural carbohydrates and nitrogenous compounds in lactating dairy cows fed diets containing timothy cut in the afternoon or morning
}

\author{
A. F. Brito, ${ }^{1 *} \odot$ G. F. Tremblay, ${ }^{2} \oplus$ A. Bertrand,${ }^{2}$ Y. Castonguay, ${ }^{2}$ G. Bélanger, ${ }^{2}$ C. Lafrenière, ${ }^{3}$ R. Martineau, ${ }^{4} \odot$ \\ and R. Berthiaume ${ }^{5}$ \\ ${ }^{1}$ University of New Hampshire, Department of Agriculture, Nutrition, and Food Systems, Durham 03824 \\ ${ }^{2}$ Soils and Crops Research and Development Centre, Agriculture and Agri-Food Canada, Québec City, QC, G1V 2J3, Canada \\ ${ }^{3}$ Agricultural Research Station, Université du Québec en Abitibi-Témiscamingue, Notre-Dame-du-Nord, QC J0Z 3B0, Canada \\ ${ }^{4}$ Dairy and Swine Research and Development Centre, Agriculture and Agri-Food Canada, Sherbrooke, QC, J1M 0C8, Canada \\ ${ }^{5}$ Private Consultant, Expert in Forage Systems, Sherbrooke, QC, J1M 0A8, Canada
}

\section{ABSTRACT}

Shifting the cutting of grass from morning to afternoon has been shown to increase the concentration of nonstructural carbohydrates (NSC) in forages. We compared the effects of diets (66:34, forage:concentrate ratio) containing a mix (\% of the diet dry matter) of baleages $(46.5 \%)$ and silages $(19.3 \%)$ harvested from timothy cut in the afternoon (p.m.-cut TIM diet) or morning (a.m.-cut TIM diet) on omasal flows of NSC and nitrogenous fractions, ruminal and total-tract digestibilities of nutrients, plasma concentration of AA, and milk yield and composition. Eight ruminally cannulated Holstein cows averaging (mean \pm standard deviation) $31.4 \pm 6.13 \mathrm{~kg} / \mathrm{d}$ of milk, $136 \pm 17.0 \mathrm{~d}$ in milk, and $611 \pm 66.4 \mathrm{~kg}$ of body weight in the beginning of the experiment were used in a crossover design with 21-d periods ( $14 \mathrm{~d}$ for diet adaptation and $7 \mathrm{~d}$ for data and sample collection). Intake of total ethanolsoluble carbohydrates (TESC; $+150 \mathrm{~g} / \mathrm{d})$, starch $(+129$ $\mathrm{g} / \mathrm{d}$ ), and total NSC (TESC plus starch $=+278 \mathrm{~g} / \mathrm{d}$ ) was greater with feeding the p.m.- than the a.m.-cut TIM diet. Likewise, the apparent ruminal digestibilities of TESC $(+149 \mathrm{~g} / \mathrm{d})$, starch $(+167 \mathrm{~g} / \mathrm{d})$, and total NSC $(+316 \mathrm{~g} / \mathrm{d})$ increased in the p.m.-cut TIM diet. Diets, however, had no effect on the omasal flows and apparent ruminal and total-tract digestibilities of dry matter and organic matter. Intake of $\mathrm{N}$ increased in cows fed the p.m.- versus the a.m.-cut TIM diet (562 and $528 \mathrm{~g} / \mathrm{d}$, respectively) despite no effect of diets on dry matter intake. Diets did not affect the omasal flows of total nonammonia $\mathrm{N}$, total bacterial nonammonia $\mathrm{N}$, nonammonia and nonbacterial $\mathrm{N}$, and individual AA, and the efficiency of microbial protein synthesis in the

Received May 31, 2021.

Accepted August 16, 2021.

*Corresponding author: andre.brito@unh.edu rumen. Contrarily, supply of rumen-degradable protein increased $(+9.2 \%)$ in cows fed the p.m.-cut TIM diet, with this response driven by the $6.4 \%$ increase in $\mathrm{N}$ intake. Plasma concentrations of essential and nonessential AA followed the omasal flow of AA and were not changed by diets. Feeding the p.m.- versus the a.m.-cut diet significantly increased yields of $4 \%$ fat-corrected milk and milk fat, and tended to increase energy-corrected milk, milk true protein, and milk lactose yields. Overall, feeding the p.m.-cut TIM diet to mid-lactation dairy cows did not improve microbial protein synthesis and omasal flow of AA, and these responses were in line with the lack of a treatment effect on dry matter intake.

Key words: diurnal cutting management, forage, microbial protein synthesis, sugar

\section{INTRODUCTION}

It is well known that carbon fixation occurs at a greater rate than carbon exportation during daylight, resulting in accumulation of sugars and starch in grass and legume forages from sunrise to sundown (Bowden et al., 1968; Lechtenberg et al., 1971; Morin et al., 2011). Specifically, shifting alfalfa (Medicago sativa L.; Brito et al., 2008) or red clover (Trifolium pratense L.; Pelletier et al., 2010; Antaya et al., 2015) cutting from morning to afternoon increased the concentration of NSC in forage tissues. Likewise, delaying cutting from morning to afternoon has been shown to increase the concentration of NSC in different grass species including timothy (Phleum pratense L.; Huntington and Burns, 2007; Pelletier et al., 2009, 2010).

Timothy is one of the most important cool-season grasses grown in colder regions of North America, Europe, and Asia (Berg et al., 1996). Previous research revealed that increased NSC concentration in timothy herbage cut in the afternoon versus morning 
was mostly driven by the increase in the concentration of sucrose (Bertrand et al., 2008; Pelletier et al., 2009). Furthermore, Pelletier et al. (2010) reported that among 8 different forage species, timothy ranked third in NSC concentration throughout cutting times and growth periods, only behind red clover and tall fescue (Festuca arundinacea Schreb.). In our companion paper (Brito et al., 2016), DMI $(+3.8 \%)$ and yields of milk fat $(+3.4 \%)$, milk true protein $(+5.5 \%), 4 \% \mathrm{FCM}$ $(+4.1 \%)$, and ECM $(+3.7 \%)$ were all greater when 16 mid-lactation cows were fed diets containing baleage and silage made from timothy cut in the afternoon (p.m.-cut TIM diet) than morning (a.m.-cut TIM diet). It is conceivable that these positive responses could be linked to increased microbial protein synthesis (MPS) with feeding the p.m.-cut TIM diet. Brito et al. (2008, 2009) observed greater DMI, milk yield, and MPS in late-lactation dairy cows fed p.m.- versus a.m.-cut alfalfa baleage as the sole dietary ingredient. Johansen et al. (2017) reported that compared with a grass-clover silage mix averaging 37\% DM and 6.05\% total sugars, feeding the drier counterpart $(61 \% \mathrm{DM}$ and $11.9 \%$ total sugars) increased the duodenal flow of microbial $\mathrm{N}$ in late-lactation dairy cows fed exclusively forage sources. However, we are not aware of any published study in which MPS and omasal flow of NSC and nitrogenous fractions were measured in lactating dairy cows receiving diets containing timothy with different NSC concentrations.

We hypothesized that increased NSC intake would enhance the supply of ruminally fermentable energy, resulting in greater MPS and omasal flow of AA in dairy cows fed the p.m.- versus the a.m.-cut TIM diet. Our objective was to compare the effects of diets with contrasting NSC concentrations (p.m.- vs. a.m.-cut TIM) on omasal flows of NSC and nitrogenous fractions, MPS, ruminal and total-tract digestibilities of nutrients, plasma concentration of $\mathrm{AA}$, and milk yield and composition.

\section{MATERIALS AND METHODS}

Care and handling of the animals used in this experiment were conducted as outlined in the Canadian Council on Animal Care (1993) guidelines. Animalrelated methods and procedures used herein were approved by the Institutional Animal Care Committee of the Agriculture and Agri-Food Canada Dairy and Swine Research and Development Centre (Sherbrooke, QC, Canada; $45^{\circ} 22^{\prime} \mathrm{N}, 71^{\circ} 52^{\prime} \mathrm{W}$ ). The current paper is part of a larger study designed to compare the effects of p.m.- versus a.m.-cut TIM diet on the production performance of 16 mid-lactation Holstein cows (Brito et al., 2016).

\section{Timothy Cutting and Harvesting}

A detailed description of the methods used for cutting and harvesting timothy as baleage or silage has been previously published (Brito et al., 2016). In brief, timothy (cultivar 'Champ') used for making baleage was grown in an 8-ha field at the Agriculture and Agri-Food Canada Research Farm (Normandin, QC, Canada; $\left.48^{\circ} 49^{\prime} \mathrm{N}, 72^{\circ} 31^{\prime} \mathrm{W}\right)$. At the heading stage of development (stages 58-60; Simon and Park, 1983) during the summer regrowth (i.e., second cut) of 2008, half of the timothy field was cut in the afternoon (1800-2030 h) on August 26, and the second half was cut in the morning (0600-0830 h) on August 27. Forage was cut using a conventional mower conditioner, tedded, and wilted to about 60\% DM (aimed between 50 and $60 \%$ DM), which was achieved on August 28 around noon (1200 h). The p.m.-cut herbage followed by its a.m.cut counterpart were harvested as baleage wrapped in stretch plastic between 1230 and $1330 \mathrm{~h}$ on August 28 . Bales $(\mathrm{n}=84)$ were then transported to the Agriculture and Agri-Food Canada Dairy Swine Research and Development Centre for the in vivo experiment.

For silage, 2 fields with a pure stand of timothy (cultivar 'Champ') yielding a total of 16 ha located at the Agriculture and Agri-Food Canada Dairy and Swine Research and Development Centre were used. In 2008, the spring growth (i.e., first cut) of half of the fields was cut in the afternoon (1800-2030 h) of June 12, and the second half was cut in the morning (0600-0830 h) of June 13 using 2 mower conditioners. Forage was wilted to approximately 30\% DM (aimed between 30 and $40 \%$ DM), which was attained around $1500 \mathrm{~h}$ on June 13 . Between 1500 and $2000 \mathrm{~h}$ of this same day, p.m.-cut followed by a.m.-cut herbage were harvested as silage and stored in 2 individual plastic silo bags.

\section{Cows, Experimental Design, and Diets}

Six ruminally cannulated multiparous Holstein cows averaging (mean $\pm \mathrm{SD}$ ) $34.0 \pm 4.53 \mathrm{~kg}$ of milk yield $/ \mathrm{d}$, $128 \pm 10.8 \mathrm{DIM}$, and $632 \pm 56.8 \mathrm{~kg}$ of $\mathrm{BW}$, and 2 ruminally cannulated primiparous Holstein cows averaging $23.8 \pm 1.77 \mathrm{~kg}$ of milk yield/d, $159 \pm 6.36$ DIM, and $548 \pm 65.1 \mathrm{~kg}$ of BW at the beginning of the experiment were blocked by parity, resulting in 1 block of multiparous cows and 1 block of primiparous cows. Within block, cows were randomly assigned to 2 dietary treatments in a crossover design with 21-d periods ( $42 \mathrm{~d}$ total) consisting of $14 \mathrm{~d}$ for diet adaptation and $7 \mathrm{~d}$ for data and sample collection. Cows were fed a TMR ad libitum once daily $(\sim 0900 \mathrm{~h})$ containing (DM basis) $34.2 \%$ of a concentrate mix plus (1) $46.5 \%$ p.m.cut timothy baleage and $19.3 \%$ p.m.-cut timothy silage 
(p.m.-cut TIM diet) or (2) $46.5 \%$ a.m.-cut timothy baleage and $19.3 \%$ a.m.-cut timothy silage (a.m.-cut TIM diet). Orts were collected every morning at 0800 $\mathrm{h}$, and the amount of TMR offered was adjusted daily to yield refusals of approximately 5 to $10 \%$ of intake. Cows were housed in a tiestall barn and had free access to water throughout the study. The concentrate mix (\% of DM) consisted of $46 \%$ cracked corn, $47 \%$ solventextracted soybean meal, and $7 \%$ of a mineral-vitamin premix. A complete description of the ingredient composition of the mineral-vitamin premix can be found in Brito et al. (2016).

\section{Ranking of Bales and Feed Sampling and Analyses}

Specific details regarding the ranking of timothy bales based on NSC concentration were reported by Brito et al. (2016). In brief, lyophilized and ground (1mm screen; Wiley mill, Arthur H. Thomas) samples of all 84 timothy bales were individually analyzed for sucrose, glucose, fructose, and starch (Blakeney and Mutton, 1980; Bertrand et al., 2007). The concentration of water-soluble carbohydrates (WSC) of each bale was calculated by adding sucrose, glucose, and fructose with starch to yield the total NSC concentration. Bales within the p.m. and a.m. cuttings were ranked from the greatest to the lowest NSC concentration. Specifically, the p.m.-cut bales with the greatest NSC concentrations were paired with the a.m.-cut bales with the greatest NSC concentrations. This pairing procedure was repeated in decreasing order of NSC concentration to create 42 pairs that were randomly assigned to each of the 42 experimental days. The goal of this ranking and pairing procedure was to maintain consistent differences in NSC concentration between the p.m.- and a.m.-cut timothy bales throughout the duration of the experiment as done previously (Brito et al., 2008, 2014).

Baleage, silage, concentrate, and TMR samples were collected daily from d 15 to 21 of each period, lyophilized, and ground (1-mm screen; Wiley mill, Arthur H. Thomas). Composited samples of baleages, silages, and concentrate, and individual samples of TMR were analyzed for sucrose, fructose, glucose, high degree of polymerization fructans, and starch (Blakeney and Mutton, 1980; Bertrand et al., 2007). An 80:20 ethanol:water solution (vol/vol) was used to partition the neutral detergent soluble carbohydrates of baleage, silage, concentrate, and TMR into organic acids and mono- and oligosaccharides, which are soluble in aqueous ethanol, from starch and neutral detergent soluble fiber, which are insoluble (Hall et al., 1999; Hall, 2000). Mono- and oligosaccharides [i.e., total ethanol-soluble carbohydrates (TESC)] were measured colorimetrically in the ethanol:water extract with the phenol-sulfuric acid method of DuBois et al. (1956) using sucrose as the standard. Starch was analyzed enzymatically on the ethanol:water insoluble residue following the method of Holm et al. (1986) as modified by Hall (2000). Glucose hydrolyzed from starch was measured using glucose oxidase-peroxidase reagent (Karkalas, 1985). Feeds and TMR were also analyzed for absolute DM (overnight at $105^{\circ} \mathrm{C}$ ), total N, NDIN, ADIN, NDF, ADF, crude fat, and AA following the procedures reported by Brito et al. (2016). Orts collected from d 15 to 21 in each period were pooled by cow, lyophilized, ground (1-mm screen; Willey mill, Arthur H. Thomas), and analyzed for absolute DM, ash, total N, NDF, and ADF concentrations (Brito et al., 2016). The complete nutritional profile of feeds and TMR have been published by Brito et al. (2016).

\section{Digestive Tract Sampling and Analyses}

Spot samples of omasal digesta were collected through the reticulo-omasal orifice using the omasal sampling technique (Huhtanen et al., 1997; Ahvenjärvi et al., 2000; Reynal et al., 2003). Indigestible NDF (Huhtanen et al., 1994), $\mathrm{YbCl}_{3}$ (Siddons et al., 1985), and CoEDTA (Udén et al., 1980) were used as digesta markers for the large particle phase $(\mathbf{L P})$, small particle phase (SP), and fluid phase (FP), respectively. In addition, ${ }^{15} \mathrm{NH}_{4} \mathrm{SO}_{4}$ enriched with 10 atom percentage excess (APE) ${ }^{15} \mathrm{~N}$ (Isotec) was used as the microbial marker for determination of MPS. The solution containing the 3 external markers (i.e., $\mathrm{YbCl}_{3}$, Co-EDTA, ${ }^{15} \mathrm{NH}_{4} \mathrm{SO}_{4}$ ) was prepared according to Reynal and Broderick (2005) and infused continuously in the rumen.

Before the beginning of the infusion, 500-mL samples of omasal digesta (background) were taken from each cow to determine the natural abundance of ${ }^{15} \mathrm{~N}$. Cows were then pulse-dosed with $2.0 \mathrm{~L}$ of the 3 -marker solution followed by continuous ruminal infusion of markers from $d 11$ to 17 at an average rate (mean \pm SD) of 3.14 $\pm 0.14 \mathrm{~kg} / \mathrm{d}$ using 4 peristaltic pumps (Masterflex L/S model no. 7523-50; Cole-Parmer Instrument Co.). This provided (mean $\pm \mathrm{SD}$ ) $2.68 \pm 0.12 \mathrm{~g}$ of $\mathrm{Co} / \mathrm{d}, 3.10 \pm$ $0.14 \mathrm{~g}$ of $\mathrm{Yb} / \mathrm{d}$, and $0.26 \mathrm{~g}$ of ${ }^{15} \mathrm{~N} / \mathrm{d}$. Omasal sampling was initiated approximately $96 \mathrm{~h}$ after beginning the marker infusion with samples collected 4 times daily at 3-h intervals over 3 consecutive days as follows: 1100 , 1400,1700 , and $2000 \mathrm{~h}$ on d 15; 1000, 1300, 1600, and $1900 \mathrm{~h}$ on d 16; and $0900,1200,1500$, and $1800 \mathrm{~h}$ on d 17 of each period. The omasal sampling device was removed from the reticulo-omasal orifice after each sampling.

Spot samples of omasal digesta $(500 \mathrm{~mL})$ collected at each of the 4 daily sampling times were split, under continuous mechanical agitation, into 2 subsamples of 
100 and $400 \mathrm{~mL}$. The 4 daily $100-\mathrm{mL}$ subsamples were pooled and stored in a refrigerator $\left(4^{\circ} \mathrm{C}\right)$ until sampling completion, followed by transportation to the laboratory for bacterial isolation. The 4 daily $400-\mathrm{mL}$ subsamples were stored at $-20^{\circ} \mathrm{C}$ and pooled over $3 \mathrm{~d}$ to obtain a single 4.8-L composite from each cow in each period for later separation into the 3 omasal phases (LP, SP, and FP). Fluid-associated bacteria (FAB) and particle-associated bacteria (PAB) were isolated using filtration and differential centrifugation as described by Brito et al. (2009). Fluid-associated bacteria and PAB pellets were stored at $-20^{\circ} \mathrm{C}$, lyophilized, ground with a mortar and pestle, and finally pooled over the $3 \mathrm{~d}$ by pellet type, cow, and period for later analysis. The 4.8-L omasal digesta composites were thawed at room temperature, separated into LP, SP, and FP via filtration and centrifugation, and stored at $-20^{\circ} \mathrm{C}$ until being lyophilized (Brito et al., 2009). After lyophilization, samples were ground through a 1-mm screen (Wiley mill; Arthur H. Thomas) and analyzed for $\mathrm{Co}$ and $\mathrm{Yb}$ in all 3 phases, and for indigestible NDF in both SP and LP based on methods detailed previously (Brito et al., 2009). Marker concentrations were used to mathematically and physically combine lyophilized FP, SP, and LP to reconstitute the omasal true digesta (DM basis) flowing past the rumen using the triple-marker method of France and Siddons (1986). Reconstituted omasal true digesta samples were analyzed for absolute DM, ash, total N, NDF, ADF, individual sugars, starch, TESC, and AA as done for feeds (Brito et al., 2016). Omasal true digesta extracts were also prepared and analyzed for $\mathrm{NH}_{3}-\mathrm{N}$ as reported by Brito et al. (2009). Samples of FAB, PAB, background omasal digesta, and omasal FP, SP, and LP were processed and analyzed for NAN and ${ }^{15} \mathrm{~N}$ following procedures outlined in Brito et al. (2009). Fluid-associated and PAB samples were further analyzed for absolute DM and ash.

Fecal grab samples were collected directly from the rectum or during voluntary defecation (d 15-17 of each period) concurrently with the omasal sampling described above. Approximately 300-g fecal samples from individual cows were collected at each time point, pooled by cow over the $3 \mathrm{~d}$ to obtain a single composite, and finally lyophilized. Dried samples were ground to pass through a 1-mm screen (Wiley mill; Arthur H. Thomas) and analyzed for absolute DM, ash, total N, NDF, ADF, starch, and TESC concentrations as described by Brito et al. (2016). Samples of feces, TMR, baleages, silages, and concentrate mix were all analyzed for acid-insoluble ash, which was used as an internal marker (Van Keulen and Young, 1977) to estimate fecal output of DM and apparent total-tract digestibility of nutrients (Cochran et al., 1986).

\section{Blood Sampling and AA Analyses}

Blood samples were collected from the coccygeal vessels approximately $4 \mathrm{~h}$ after the morning feeding on $\mathrm{d}$ 18 of each period into vacutainer tubes (Becton Dickinson) containing sodium heparin. Tubes were kept on ice until transported to the laboratory and centrifuged $\left(2,000 \times g, 12 \mathrm{~min}, 4^{\circ} \mathrm{C}\right)$ to obtain plasma. Next, $0.2 \mathrm{~g}$ of an internal standard solution of stable isotope-labeled AA $\left({ }^{13} \mathrm{C}\right.$ and ${ }^{15} \mathrm{~N}$ AA isotope standards; CDN isotopes, Pointe-Claire; Cambridge Isotope Laboratories Inc.) was gravimetrically added to $1 \mathrm{~g}$ of plasma and stored at $-80^{\circ} \mathrm{C}$ until AA analyses. Plasma concentrations of individual AA were determined by the isotope dilution method using a GC-MS instrument (Hewlett-Packard model GC6890-MS5973, Agilent Technologies) as reported in Brito et al. (2016).

\section{Milk Sampling and Analyses}

Cows were milked twice daily at approximately 0600 and $2000 \mathrm{~h}$, with milk yield recorded every milking throughout the experiment. Milk samples were collected from d 14 (afternoon) to d 21 (morning) of each experimental period, preserved in tubes containing 2-bromo-2-nitropropane 1,3 diol, and kept at $4^{\circ} \mathrm{C}$ until shipped to Lactanet (Sainte-Anne-de-Bellevue, QC, Canada) for determination of fat, true protein, lactose, and MUN by mid-infrared reflectance spectroscopy.

\section{Calculations}

Omasal flow of NAN was calculated by subtracting $\mathrm{NH}_{3}-\mathrm{N}$ flow from total $\mathrm{N}$ flow. Total NAN omasal flow was obtained by adding PAB NAN, FAB NAN, and nonammonia and nonbacterial N (NANBN) flows. The natural abundance of ${ }^{15} \mathrm{~N}$ in samples from background omasal digesta averaged (mean \pm SD) 0.36746 \pm 0.000076 atom percentage. Enrichment of ${ }^{15} \mathrm{~N}$, which represents ${ }^{15} \mathrm{~N}$ APE above the natural abundance of ${ }^{15} \mathrm{~N}$ measured from background omasal digesta samples, was calculated as follows:

$$
\begin{gathered}
{ }^{15} \mathrm{~N} \text { APE }\left({ }^{15} \mathrm{~N} \text { enrichment }\right)={ }^{15} \mathrm{~N} \text { atom percentage } \\
\text { - background }{ }^{15} \mathrm{~N} \text { atom percentage. }
\end{gathered}
$$

Based on the assumption that FAB and PAB represent ruminal bacteria associated with $\mathrm{FP}$ and particle phase (i.e., SP plus LP), respectively, omasal flows of FAB NAN, PAB NAN, and total bacterial NAN were calculated as follows: 
FAB NAN flow $=$ FP NAN flow

$\times\left(\mathrm{FP}^{15} \mathrm{~N} \mathrm{APE} / \mathrm{FAB}{ }^{15} \mathrm{~N}\right.$ APE $)$;

PAB NAN flow $=$ particle phase NAN flow

$\times\left(\right.$ particle phase ${ }^{15} \mathrm{~N}$ APE $/ \mathrm{PAB}{ }^{15} \mathrm{~N}$ APE $)$;

Total bacterial NAN flow $=$ FAB NAN flow

+ PAB NAN flow.

Omasal flow of NANBN, RUP and RDP supplies, and organic matter truly digested in the rumen (OMTDR) were calculated as follows:

$$
\begin{gathered}
\text { NANBN flow }=\text { total NAN flow } \\
- \text { total bacterial NAN flow; } \\
\text { RUP supply }=(\text { total N flow } \\
- \text { total bacterial NAN flow }) \times 6.25 ; \\
\text { RDP supply }=\text { CP intake }- \text { RUP supply; } \\
\text { OMTDR }=\text { OM intake } \\
- \text { (omasal OM flow }- \text { total bacterial OM flow })
\end{gathered}
$$

where all flows and intakes are in grams or kilograms per day. Efficiency of microbial protein synthesis (EMPS) was calculated as the ratio between total bacterial NAN flow $(\mathrm{g} / \mathrm{d})$ and OMTDR $(\mathrm{kg} / \mathrm{d})$.

\section{Statistical Analyses}

Data were analyzed using the MIXED procedure of SAS (version 9.4, SAS Institute Inc.) according to the following statistical model:

$$
\begin{aligned}
\mathrm{Y}_{\mathrm{ijklm}} & =\mu+\operatorname{Seq}_{\mathrm{i}}+\mathrm{C}_{\mathrm{j}}(\mathrm{Seq})_{\mathrm{i}}+\operatorname{Per}_{\mathrm{k}} \\
& +\operatorname{Trt}_{1}+\operatorname{Par}_{\mathrm{m}}+\varepsilon_{\mathrm{ijk} k \mathrm{~m}},
\end{aligned}
$$

where $\mathrm{Y}_{\mathrm{ijklm}}=$ dependent variable response $(\mathrm{n}=16$ observations) during the kth period of the jth cow in the ith sequence group $(\mathrm{i}=1,2 ; \mathrm{j}=1,2, . ., 8 ; \mathrm{k}$ $=1,2), \mu=$ overall mean, Seq $_{\mathrm{i}}=$ effect of the ith crossover sequence group $(i=1,2), C_{j}(\text { Seq })_{i}=$ effect of the jth cow nested within the ith sequence group, $\operatorname{Per}_{\mathrm{k}}=$ effect of the kth period $(\mathrm{k}=1,2$; equivalent to treatment $\times$ sequence interaction), Trt $_{1}=$ effect of the lth treatment $(1=1,2), \mathrm{Par}_{\mathrm{m}}=$ effect of the mth parity $(\mathrm{m}=$ multiparous or primiparous cows, with parity used as a blocking factor), and $\varepsilon_{\mathrm{ijk} k \mathrm{~m}}=$ random residual variation. Sequence indicates the order in which treat- ments were allocated (i.e., sequence $1=$ p.m.-cut TIM followed by a.m.-cut TIM and sequence $2=$ a.m.-cut TIM followed by p.m.-cut TIM) and was determined a priori. The experimental units (i.e., individual cows) were then randomly distributed to sequence $1(\mathrm{n}=4)$ or sequence $2(\mathrm{n}=4)$. All terms were entered as fixed in the statistical model except for $\mathrm{C}_{\mathrm{j}}(\mathrm{Seq})_{\mathrm{i}}$ and $\varepsilon_{\mathrm{ijk} k \mathrm{~m}}$, which were considered random. Values are presented as least squares means and standard error of the mean. Differences between least squares means were reported only if the F-test for treatment was significant at $P \leq$ 0.05 , with trends declared at $0.05<P \leq 0.10$.

\section{RESULTS AND DISCUSSION}

The nutritional profile of the timothy baleages and silages and that of the concentrate mix can be found in Brito et al. (2016). Briefly, the concentrations of individual sugars (i.e., sucrose, glucose, fructose), WSC, TESC, starch, and NSC (WSC plus starch or TESC plus starch) of baleage and silage increased in the p.m.- versus the a.m.-cut timothy (Brito et al., 2016). Consequently, the NSC concentration of the p.m.-cut TIM diet was, on average, $7 \%$ greater than that of the a.m.-cut TIM diet (Brito et al., 2016). Increased NSC concentrations in the p.m.-cut timothy baleage and p.m.-cut timothy silage occurred at the expense of NDF (decreased by 2.7 percentage units) and $\mathrm{CP}$ (decreased by 0.7 percentage unit), respectively (Brito et al., 2016).

Our diets contained (DM basis) $19.3 \%$ of timothy silage, which contributed to the small difference in total NSC concentration between the p.m.- and a.m.cut TIM treatments, as sugars are more intensively fermented in wetter than drier silages (Johansen et al., 2017). However, the number of bales produced and eligible to be used in the experiment based on NSC concentrations was limited ( $\mathrm{n}=42$ pairs). Therefore, silages were included in the diets to ensure that cows would receive the target 66:34 forage-to-concentrate ratio if bales had to be discarded due to spoilage. Another justification to feed silages was that previous mini-silo research done by our group showed that conservation attributes during storage improved in alfalfa silage with increased NSC concentration (Tremblay et al., 2014). For instance, when NSC concentration differences at ensiling were $>1 \%$ between p.m.- and a.m.-cut alfalfa, silage $\mathrm{pH}(-0.2$ to -0.4$)$ and concentrations of VFA $(-0.8$ to $-1.1 \%$ of $\mathrm{DM})$ and $\mathrm{NH}_{3}-\mathrm{N}(-0.6$ to $-1.1 \%$ of total $\mathrm{N}$ ) decreased, and lactic acid concentration increased $(+0.8$ to $+2.0 \%$ of DM; Tremblay et al., 2014). In the present study, the concentrations of total NSC (calculated as TESC plus starch) at ensiling averaged 7.19 and $5.88 \%$ for the p.m.- and a.m.-cut 
timothy silage, respectively (data not shown). Notice that the concentration of lactic acid, as a proportion of total organic acids, increased from $69 \%$ in the a.m.-cut timothy silage to $74 \%$ in the p.m.-cut timothy silage concomitantly with decreased concentrations of acetic and propionic acids and ethanol (Brito et al., 2016). According to Tremblay et al. (2014), increased dietary NSC concentration together with improved silage fermentation profile may synergistically act to enhance DMI and milk yield in dairy cows. In fact, DMI increased significantly, and milk yield tended to increase with feeding the p.m.- versus the a.m.-cut TIM diet to 16 dairy cows (Brito et al., 2016).

\section{Intake, Digestibility, and Omasal Flows of DM, OM, and NSC Fractions}

Intake (d 15-17 of the omasal sampling period), apparent ruminal and total-tract digestibilities, and omasal flows of DM and OM, as well as OMTDR did not differ $(P \geq 0.21)$ between the p.m.- and a.m.-cut TIM diets (Table 1$)$. These results are in line with the relatively small increase $(P<0.01 ;+278 \mathrm{~g} / \mathrm{d})$ in total NSC intake (TESC plus starch) with feeding the p.m.cut TIM diet (Table 1). We also noted that the difference in total NSC concentration between the p.m.- and a.m.-cut TIM diets narrowed due to the dilution of timothy NSC with starch and sugars supplied by the concentrate mix (Brito et al., 2016). No treatment effects were observed for intake, omasal flows, and apparent ruminal and total-tract digestibilities of NDF and ADF (data not shown).

We are not aware of any published research that has investigated the effects of diets containing timothy submitted to diurnal cutting management, harvested as baleage or silage, on omasal flow and ruminal digestibility of nutrients. There are also few in vivo data on how forages with contrasting NSC concentrations affect MPS in the rumen. Brito et al. (2009) reported that the omasal flows of DM and OM tended to increase in lactating dairy cows fed p.m.- rather than a.m.-cut alfalfa baleage as the sole dietary ingredient, but no treatment effect was detected for DM and OM apparently and truly digested in the rumen. In a subsequent study, Brito et al. (2014) found no changes in the omasal flow of OM, as well as OM apparently or truly digested in the rumen in lactating dairy cows offered diets containing high- versus low-NSC alfalfa baleage supplemented with a cracked corn-soybean meal-based concentrate mix (53:47 forage:concentrate ratio). Lee et al. (2002) demonstrated that although the duodenal flow of OM increased in crossbred Hereford $\times$ Friesian steers fed high- rather than low-WSC perennial ryegrass (Lolium perenne L.), DM and $\mathrm{OM}$ apparently digested in the rumen did not differ between diets. Recently, Johansen et al. (2017) observed no treatment effects on the duodenal flow and apparent ruminal digestibility of DM in late-lactation dairy cows offered grass-clover silage mixes ranging from 28.3 to $72.5 \% \mathrm{DM}$ and total sugars from 1.42 to $16.4 \%$. However, the duodenal flow of OM increased, and $\mathrm{OM}$ apparently digested in the rumen decreased with varying the concentrations of DM and total sugars (Johansen et al., 2017). In general, our omasal flows and ruminal digestibilities of DM and OM data (Table 1) corroborate earlier findings (i.e., Brito et al., 2009, 2014) and partially agree with Lee et al. (2002) and Johansen et al. (2017).

Intake of TESC, starch (measured according to Hall, 2000), and total NSC (calculated as TESC plus starch) were all greater $(P \leq 0.02)$ in cows fed the p.m.- than the a.m.-cut TIM diet (Table 1). Increased intake of these NSC fractions can be explained by the improved concentrations of sugars and starch with shifting timothy cutting from morning to afternoon (Brito et al., 2016). The present results partially agree with those from Brito et al. (2014), who reported a $17.5 \%$ increase in TESC intake $(+119 \mathrm{~g} / \mathrm{d})$ but no change on total NSC intake (TESC plus starch) in lactating dairy cows offered high- versus low-NSC alfalfa baleage supplemented with concentrate. No effect of diets was observed for the omasal flows of TESC, starch, and total NSC, which averaged 38.4, 243, and $281 \mathrm{~g} / \mathrm{d}$, respectively (Table 1 ). The amounts of TESC, starch, and NSC digested in the rumen increased $(P \leq 0.02)$ with feeding the p.m.-cut TIM and were likely associated with enhanced intake of TESC, starch, and NSC. However, the ruminal digestibilities of TESC, starch, and total NSC, expressed as a proportion of intake, did not differ $(P \geq 0.15)$ between diets. As expected, most TESC $($ mean $=96 \%)$, starch $($ mean $=81.6 \%)$, and total NSC (mean $=87.9 \%$ ) were digested in the rumen, which agree with Brito et al. (2014). We further observed that the omasal flows of maltose $($ mean $=21$ $\mathrm{g} / \mathrm{d}$ ), starch (mean $=371 \mathrm{~g} / \mathrm{d}$; measured according to Bertrand et al., 2007), and NSC (calculated as maltose plus starch; mean $=392 \mathrm{~g} / \mathrm{d}$ ) were not affected by diet (Table 1). Overall, the effect of diet with contrasting NSC concentrations on the omasal flow and ruminal digestibility of NSC fractions was minor, but consistent with the small increase in total NSC intake $(+278 \mathrm{~g} / \mathrm{d})$ when cows received the p.m.-cut TIM diet (Table 1).

\section{Intake, Digestibility, and Omasal Flow of Nitrogenous Fractions}

Intake of $\mathrm{N}$ increased by $6.4 \%(P=0.05)$ in cows fed the p.m.- $(562 \mathrm{~g} / \mathrm{d})$ versus the a.m.-cut TIM diet (528 $\mathrm{g} / \mathrm{d}$ ) despite the lack of treatment effect on DMI (Table 
Table 1. Intake ${ }^{1}$ and apparent total-tract digestibilities ${ }^{2}$ of DM, OM, and NSC fractions in mid-lactation dairy cows fed diets containing p.m.cut timothy baleage and silage (p.m.-cut TIM diet) or a.m.-cut timothy baleage and silage (a.m.-cut TIM diet) supplemented with a cracked corn-soybean meal-based concentrate mix

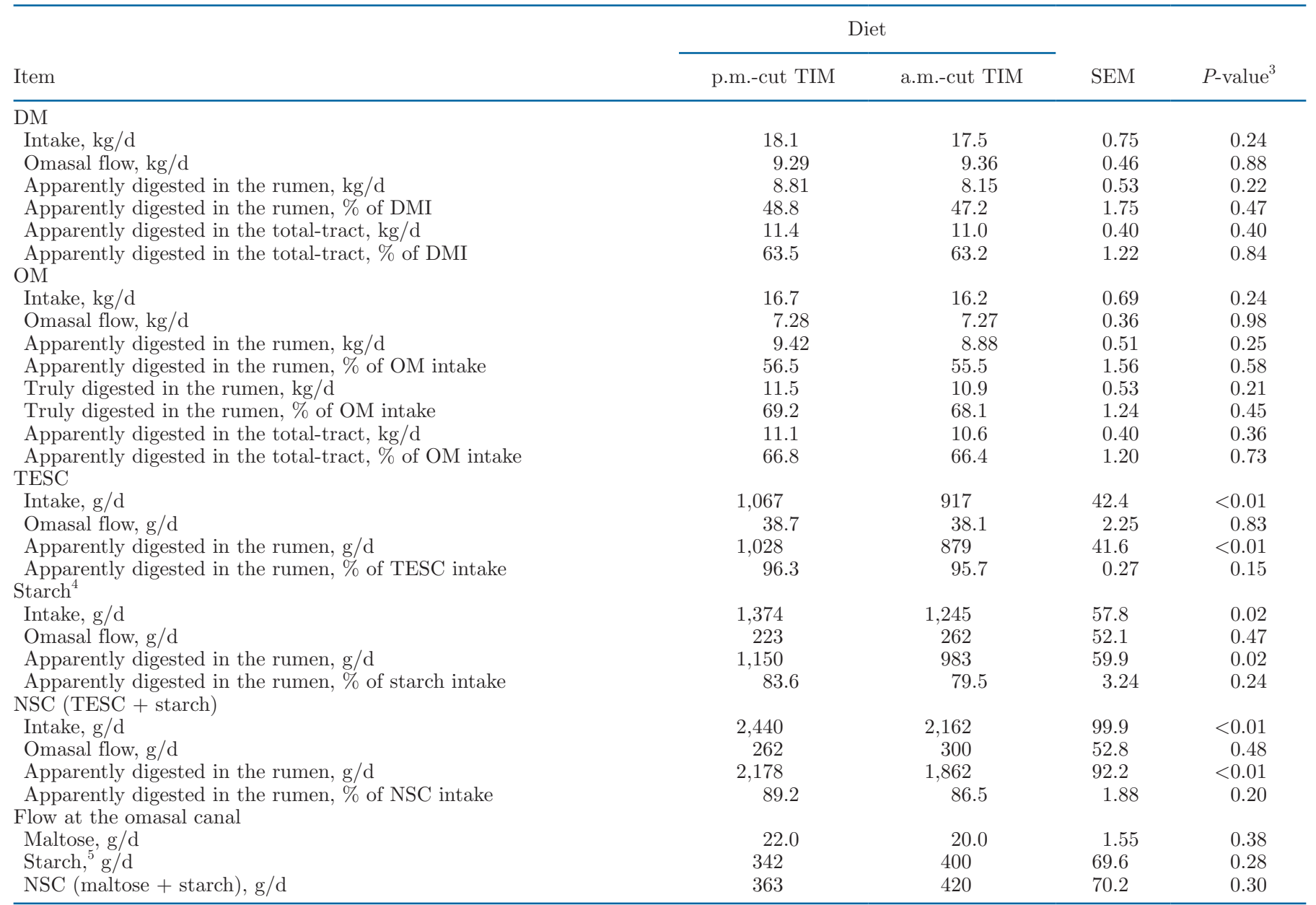

${ }^{1}$ Intake presented in this table corresponds to d 15 to 17 (omasal sampling period), with dietary concentrations of nutrients averaging $56.7 \%$ (p.m.-cut TIM) and 50.6\% (a.m.-cut TIM) for DM, $92.1 \%$ (p.m.-cut TIM) and 92.1\% (a.m.-cut TIM) for OM, 5.86\% (p.m.-cut TIM) and 5.27\% (a.m.-cut TIM) for total ethanol-soluble carbohydrates (TESC), 7.61\% (p.m.-cut TIM) and 7.16\% (a.m.-cut TIM) for starch, and 13.5\% (p.m.cut TIM) and $12.4 \%$ (a.m.-cut TIM) for NSC (TESC + starch).

${ }^{2}$ Fecal output of DM and apparent total-tract digestibilities of DM and OM was estimated using acid-insoluble ash (AIA) from p.m.- and a.m.cut TIM TMR samples collected during d 15 to 17, with AIA concentrations averaging (DM basis) 1.42\% for both diets; AIA concentrations of pooled samples of p.m.-cut timothy baleage, a.m.-cut timothy baleage, p.m.-cut timothy silage, a.m.-cut timothy silage, and concentrate mix collected from d 15 to 21 of each period averaged (DM basis) 2.73, 2.38, 0.990, 0.989, and 0.65\%, respectively.

${ }^{3}$ Probability of treatment effect (p.m.-TIM vs. a.m.-TIM); significance was declared at $P \leq 0.05$ and trends at $0.05<P \leq 0.10$.

${ }^{4}$ Analyzed as glucose equivalent using oxidase-peroxidase after sample extraction with ethanol (Hall, 2000).

${ }^{5}$ Analyzed as glucose equivalent using $p$-hydroxybenzoic acid hydrazide after extraction with methanol-chloroform-water (Blakeney and Mutton, 1980).

2). Both DMI (+3.8\%) and N intake (+5.1\%) increased significantly with feeding the p.m.-cut TIM diet when all 16 cows were included in the statistical analyses (Brito et al., 2016). Supply of RDP was greater $(P=$ $0.05)$ in the p.m.- than the a.m.-cut TIM $\operatorname{diet}(2,853$ vs. $2,613 \mathrm{~g} / \mathrm{d}$, respectively; Table 2), most likely because of the increased $\mathrm{N}$ intake. Furthermore, RDP supply, expressed as a proportion of DMI, tended $(P=0.10)$ to increase in the p.m.- versus the a.m.-cut TIM diet (15.8 vs. $15.1 \%$, respectively). However, no treatment difference was observed for RUP supply (means $=675$ $\mathrm{g} / \mathrm{d}$ and $3.76 \%$ of DMI) or $\mathrm{N}$ apparently digested in the rumen (means $=235 \mathrm{~g} / \mathrm{d}$ and $43.5 \%$ of $\mathrm{N}$ intake; Table 2). In contrast, the amount of $\mathrm{N}$ truly digested in the rumen was greater $(+9.1 \% ; P=0.05)$ in the p.m.- than the a.m.-cut TIM diet, also in line with increased $\mathrm{N}$ intake. The omasal flow of NAN per kilogram of DMI (mean $=17 \mathrm{~g} / \mathrm{kg}$; data not shown) was, on average, $31 \%$ lower than that reported in the metaanalysis of Broderick et al. (2010; mean $=24.7 \mathrm{~g} / \mathrm{kg}$ ), 
suggesting that both DM and OM flows may have been underestimated in our experiment. Compared with the present study, the omasal flow of OM, per kilogram of OM intake, was $20 \%$ greater in Broderick et al. (2010). Assuming a similar magnitude increase of $20 \%$ in the mean omasal flow of DM in our study, NAN flow would have increased from 17 to $22.2 \mathrm{~g} / \mathrm{kg}$ of DMI or $10 \%$ lower than the mean value published by Broderick et al. (2010). According to Titgemeyer (1997), EMPS can be used as a tool to assess whether problems exist in digesta-marker behavior because it is calculated as the ratio between bacterial $\mathrm{N}$ flow and $\mathrm{OM}$ fermented in the rumen, which are positively and negatively related to total digesta flow, respectively. Therefore, if digesta flow is overestimated, the calculation of EMPS is exponentially biased. Efficiency of MPS (mean $=22.1 \mathrm{~g}$ of bacterial NAN $/ \mathrm{kg}$ of OMTDR) measured in the current experiment was within the range expected for high quality diets $(20-25 \mathrm{~g}$ of bacterial $\mathrm{N} / \mathrm{kg}$ of OMTDR; Titgemeyer, 1997), as well as within the range reported in the meta-analysis of Roman-Garcia et al. (2016) using duodenal and omasal flow studies (12-54 g of bacterial $\mathrm{N} / \mathrm{kg}$ of OMTDR; mean $=28.7 \mathrm{~g}$ of bacterial $\mathrm{N} /$ $\mathrm{kg}$ of OMTDR). Moreover, our EMPS data were close to the mean EMPS value of $23.7 \mathrm{~g}$ of bacterial $\mathrm{N} / \mathrm{kg}$ of OMTDR (range from 13.5-30.8 $\mathrm{g}$ of $\mathrm{N} / \mathrm{kg}$ of OMTDR) showed in the meta-analysis of Broderick et al. (2010), who exclusively used experiments conducted with the omasal sampling technique. Although the less than expected omasal flow of NAN is challenging to explain, it was likely influenced by multiple factors, including potential accumulative errors associated with using 3 different markers to estimate flows and reconstitute the omasal true digesta.

Nitrogen apparently digested in the total-tract tended $(+7.3 \% ; P=0.07)$ to increase in cows receiving the p.m.- versus the a.m.-cut TIM diet, but no effect $(P$ $=0.73)$ was observed when total-tract $\mathrm{N}$ digestibility was expressed as a proportion of $\mathrm{N}$ intake (mean = $67.8 \%$ ). There are few in vivo data on the effects of forages with different NSC concentrations on ruminal digestibility, flow of nutrients, and MPS in lactating dairy cows. Therefore, our ability to compare the present results against those published in the literature is limited. Brito et al. (2009, 2014) observed no changes in the amounts of RDP supply and $\mathrm{N}$ truly digested in the rumen in lactating dairy cows fed alfalfa baleage-based diets with varying NSC concentrations, thus in agreement with current findings. In contrast, Johansen et al. (2017) reported decreased apparent and true ruminal digestibilities of $\mathrm{CP}$ with feeding grasslegume silage mixes with increasing concentrations of DM (28.3-72.5\%) and total sugars $(1.42-16.4 \%)$ to late-lactation dairy cows.
Omasal flows of total $\mathrm{N}, \mathrm{NH}_{3}-\mathrm{N}, \mathrm{NAN}$, and NANBN, as well as EMPS, were not affected $(P \geq 0.14)$ by diets (Table 2). This lack of response was not surprising because the actual differences in N and NSC intake between diets, despite being significant $(P \leq 0.05)$, were not large enough to elicit changes in the omasal flow of nitrogenous compounds. Likewise, the omasal flows of PAB NAN $($ mean $=112 \mathrm{~g} / \mathrm{d})$, FAB NAN $($ mean $=90.2$ $\mathrm{g} / \mathrm{d}$ ), and total bacterial NAN (mean $=202 \mathrm{~g} / \mathrm{d}$ ) $\mathrm{did}$ not differ $(P \geq 0.48$; Table 2$)$. On average, PAB NAN $(55.4 \%)$ contributed to a greater proportion of the total bacterial NAN flow than FAB NAN (44.6\%), which agrees with some (e.g., Reynal and Broderick, 2005; Brito et al., 2009, 2014), but not all, omasal sampling studies (e.g., Olmos Colmenero and Broderick, 2006).

Previous research revealed that the omasal flow of total bacterial NAN increased by $6.8 \%$ (332 vs. 311 g/d) when p.m.- rather than a.m.-cut alfalfa baleage was fed to lactating dairy cows as the sole dietary ingredient (Brito et al., 2009). Similarly, Berthiaume et al. (2010) observed greater MPS (+14.3\%; 263 vs. $230 \mathrm{mg} / \mathrm{d}$ ) in dual-flow continuous culture fermentors dosed with high- versus low-NSC alfalfa herbage. Studies done with growing beef steers also showed that the duodenal flow of bacterial $\mathrm{N}$ improved from $27 \%$ (101 vs. $79.9 \mathrm{~g} / \mathrm{d}$; Lee et al., 2002) to $52 \%$ (63.2 vs. 41.7 $\mathrm{g} / \mathrm{d}$; Merry et al., 2006) in diets containing high- versus low-WSC perennial ryegrass offered as fresh herbage or silage. Contrarily, feeding high- versus low-NSC alfalfa baleage supplemented with concentrate did not affect the omasal flow of total bacterial NAN (mean $=354$ $\mathrm{g} / \mathrm{d}$ ) in lactating dairy cows in the experiment of Brito et al. (2014). Collectively, data from Brito et al. (2014) and the current experiment suggest that concentrate supplementation reduced or offset the effects of forage NSC on MPS because MPS increased in studies where high-NSC forage was used without concentrate supplementation (i.e., Lee et al., 2002; Merry et al., 2006; Brito et al., 2009). However, Kokko et al. (2013) reported no treatment effect on MPS (mean $=270$ $\mathrm{mg} / \mathrm{d}$ ) in dual-flow continuous culture fermentors receiving p.m.- versus a.m.-cut birdsfoot trefoil (Lotus corniculatus L.)-timothy mixed hay without concentrate. We further noted that inclusion of timothy silage diluted the NSC concentration of the forage portion of the diet in our study because silage is more intensively fermented than baleage, which likely contributed to the narrow difference in NSC concentration between the p.m.- and a.m.-cut TIM diets and the lack of effect on MPS. Johansen et al. (2017) demonstrated a reduction in the concentration of total sugars from 16.4 to $1.42 \%$ when the DM levels of grass-clover silage mixes dropped from 72.5 to $32.2 \%$. Discrepancies in MPS across the experiments cited above can be also explained by dif- 
Table 2. Nitrogen intake, ${ }^{1}$ omasal flow of nitrogenous fractions, and apparent total-tract digestibility ${ }^{2}$ of $\mathrm{N}$ in mid-lactation dairy cows fed diets containing p.m.-cut timothy baleage and silage (p.m.-cut TIM diet) or a.m.-cut timothy baleage and silage (a.m.-cut TIM diet) supplemented with a cracked corn-soybean meal-based concentrate mix

\begin{tabular}{|c|c|c|c|c|}
\hline Item & \multicolumn{2}{|c|}{ Diet } & SEM & $P$-value ${ }^{3}$ \\
\hline $\mathrm{N}$ intake, $\mathrm{g} / \mathrm{d}$ & 562 & 528 & 21.9 & 0.05 \\
\hline RDP supply, \% of DMI & 15.8 & 15.1 & 0.30 & 0.10 \\
\hline RUP supply, g/d & 662 & 687 & 59.8 & 0.67 \\
\hline RUP supply, \% of DMI & 3.67 & 3.85 & 0.25 & 0.57 \\
\hline $\mathrm{N}$ truly digested in the rumen, $\mathrm{g} / \mathrm{d}$ & 456 & 418 & 18.0 & 0.05 \\
\hline $\mathrm{N}$ truly digested in the rumen, $\%$ of $\mathrm{N}$ intake & 81.1 & 79.6 & 1.36 & 0.38 \\
\hline $\mathrm{N}$ apparently digested in the total-tract, $\mathrm{g} / \mathrm{d}$ & 381 & 355 & 11.7 & 0.07 \\
\hline $\mathrm{N}$ apparently digested in the total-tract, $\%$ of $\mathrm{N}$ intake & 68.0 & 67.6 & 1.07 & 0.73 \\
\hline \multicolumn{5}{|l|}{ Flow at the omasal canal } \\
\hline $\mathrm{N}, \mathrm{g} / \mathrm{d}$ & 313 & 307 & 18.0 & 0.80 \\
\hline $\mathrm{N}, \%$ of $\mathrm{N}$ intake & 55.5 & 57.5 & 2.45 & 0.54 \\
\hline \multirow{2}{*}{\multicolumn{5}{|c|}{ FAB $^{5}$ NAN }} \\
\hline & & & & \\
\hline $\mathrm{g} / \mathrm{d}$ & 92.5 & 87.8 & 5.03 & 0.51 \\
\hline$\%$ of total bacterial NAN flow & 44.8 & 44.4 & 0.91 & 0.78 \\
\hline \multicolumn{5}{|l|}{ Total bacterial NAN } \\
\hline $\mathrm{g} / \mathrm{d}$ & 207 & 197 & 9.41 & 0.48 \\
\hline$\%$ of NAN flow & 67.5 & 66.1 & 1.26 & 0.39 \\
\hline NANBN, ${ }^{6} \mathrm{~g} / \mathrm{d}$ & 98.5 & 104 & 9.23 & 0.59 \\
\hline NANBN, $\%$ of NAN flow & 32.5 & 33.9 & 1.26 & 0.39 \\
\hline NANBN, $\%$ of $\mathrm{N}$ intake & 17.6 & 19.3 & 1.31 & 0.35 \\
\hline NANBN, \% of DMI & 0.55 & 0.58 & 0.04 & 0.51 \\
\hline \multicolumn{5}{|l|}{ Efficiency of microbial protein synthesis } \\
\hline $\mathrm{g}$ of total bacterial NAN $/ \mathrm{kg}$ of $\mathrm{OMADR}^{7}$ & 18.3 & 17.3 & 1.68 & 0.47 \\
\hline $\mathrm{g}$ of total bacterial NAN $/ \mathrm{kg}$ of $\mathrm{OMTDR}^{8}$ & 23.0 & 21.2 & 2.61 & 0.42 \\
\hline
\end{tabular}

${ }^{1}$ Intake presented in this table corresponds to d 15 to 17 (omasal sampling period), with dietary concentrations of CP averaging $18.1 \%$ (p.m.-cut TIM) and $17.9 \%$ (a.m.-cut TIM).

${ }^{2}$ Fecal output of DM and apparent total-tract digestibility of $\mathrm{N}$ was estimated with acid-insoluble ash (AIA) using p.m.- and a.m.-cut TIM TMR samples collected during d 15 to 17, with AIA concentrations averaging (DM basis) $1.42 \%$ for both diets; AIA concentrations of pooled samples of p.m.-cut timothy baleage, a.m.-cut timothy baleage, p.m.-cut timothy silage, a.m.-cut timothy silage, and concentrate mix collected from d 15 to 21 of each period averaged (DM basis) $2.73,2.38,0.990,0.989$, and $0.65 \%$, respectively.

${ }^{3}$ Probability of treatment effect (p.m.-TIM vs. a.m.-TIM diet); significance was declared at $P \leq 0.05$ and trends at $0.05<P \leq 0.10$

${ }^{4} \mathrm{PAB}=$ particle-associated bacteria.

${ }^{5} \mathrm{FAB}=$ fluid-associated bacteria.

${ }^{6} \mathrm{NANBN}=$ nonammonia, nonbacterial $\mathrm{N}$.

${ }^{7} \mathrm{OMADR}=$ organic matter apparently digested in the rumen.

${ }^{8} \mathrm{OMTDR}=$ organic matter truly digested in the rumen

ferences in the following: (1) forage sources (grasses vs. legumes), (2) feeding management (TMR vs. component feeding), and (3) type of experiment (in vitro vs. in vivo).

\section{Omasal Flow and Plasma Concentration of AA}

No effect of diets $(P \geq 0.46)$ was observed for the omasal flow of any individual EAA or NEAA (Table 3). Consequently, the omasal flows of total branched-chain AA $($ mean $=299 \mathrm{~g} / \mathrm{d})$, total EAA $($ mean $=634 \mathrm{~g} / \mathrm{d})$, total NEAA $($ mean $=784 \mathrm{~g} / \mathrm{d})$, and total AA $($ mean $=$ $1,419 \mathrm{~g} / \mathrm{d})$ did not differ $(P \geq 0.75)$ between diets (Table $3)$. The Lys:Met ratio in the omasal true digesta tended $(P=0.06)$ to be greater with feeding the p.m.- versus the a.m.-cut TIM diet. However, the omasal flows of Lys and Met, expressed in grams per day (Table 3) or as a proportion of DMI (data not shown), did not differ significantly between diets, suggesting that the increase in the Lys:Met ratio was an artifact of the calculation. We observed few changes in the omasal flows of EAA and NEAA in our previous research using dairy 
Table 3. Omasal flow of AA in mid-lactation dairy cows fed diets containing p.m.-cut timothy baleage and silage (p.m.-cut TIM diet) or a.m.-cut timothy baleage and silage (a.m.-cut TIM diet) supplemented with a cracked corn-soybean meal-based concentrate mix

\begin{tabular}{|c|c|c|c|c|}
\hline \multirow[b]{2}{*}{ Item } & \multicolumn{2}{|c|}{ Diet } & \multirow[b]{2}{*}{ SEM } & \multirow[b]{2}{*}{$P$-value ${ }^{1}$} \\
\hline & p.m.-cut TIM & a.m.-cut TIM & & \\
\hline \multicolumn{5}{|l|}{$\overline{E A A}, g / d$} \\
\hline His & 29.6 & 29.3 & 1.98 & 0.91 \\
\hline Ile & 83.3 & 80.7 & 4.91 & 0.66 \\
\hline Leu & 137 & 135 & 9.21 & 0.87 \\
\hline Lys & 91.0 & 86.5 & 5.30 & 0.46 \\
\hline Met & 45.9 & 46.2 & 3.31 & 0.93 \\
\hline Phe & 86.5 & 85.7 & 5.65 & 0.90 \\
\hline Thr & 87.0 & 85.8 & 5.47 & 0.86 \\
\hline Val & 82.4 & 79.5 & 5.04 & 0.65 \\
\hline \multicolumn{5}{|l|}{ NEAA, g/d } \\
\hline Ala & 106 & 103 & 7.04 & 0.71 \\
\hline Asp & 192 & 186 & 13.0 & 0.71 \\
\hline Glu & 179 & 178 & 12.4 & 0.93 \\
\hline Gly & 85.8 & 85.2 & 5.47 & 0.92 \\
\hline Pro & 72.3 & 73.5 & 5.31 & 0.82 \\
\hline Ser & 81.0 & 81.3 & 5.60 & 0.96 \\
\hline Tyr & 72.9 & 71.8 & 4.58 & 0.84 \\
\hline \multicolumn{5}{|l|}{ Sum and ratio of $\mathrm{AA}$} \\
\hline Total branched-chain AA, g/d & 302 & 295 & 19.1 & 0.75 \\
\hline Total EAA, g/d & 642 & 629 & 40.5 & 0.77 \\
\hline Total NEAA, $\mathrm{g} / \mathrm{d}$ & 788 & 779 & 53.2 & 0.87 \\
\hline Total AA, g/d & 1,431 & 1,407 & 93.5 & 0.83 \\
\hline Lys:Met ratio & 1.98 & 1.89 & 0.04 & 0.06 \\
\hline
\end{tabular}

${ }^{1}$ Probability of treatment effect (p.m.-TIM vs. a.m.-TIM diet); significance was declared at $P \leq 0.05$ and trends at $0.05<P \leq 0.10$.

cows fed exclusively p.m.- versus a.m.-cut alfalfa baleage (Brito et al., 2009) or high- versus low-NSC alfalfa supplemented with concentrate (Brito et al., 2014). In contrast, Lee et al. (2002) reported that, except for the duodenal flows of Arg and Gly, all remaining EAA and NEAA either tended to increase or increased significantly in beef steers receiving high-WSC perennial ryegrass compared with the low-WSC counterpart. Lee et al. (2002) observed greater DMI ( $+39 \%$; 9.3 vs. 6.7 $\mathrm{kg} / \mathrm{d})$ and MPS (+27\%; 101 vs. $79.9 \mathrm{~g} / \mathrm{d})$ with feeding the high- rather than low-WSC perennial ryegrass to beef steers, which likely contributed to the increased duodenal flows of EAA and NEAA.

Except for plasma Val concentration, which tended $(P=0.07)$ to increase with feeding the p.m.- (mean $=240 \mu M)$ than the a.m.-cut TIM $($ mean $=223 \mu M)$ diet, concentrations of all remaining EAA and NEAA in plasma were not affected $(P \geq 0.18)$ by treatments (Table 4). Furthermore, the plasma concentrations of total branched-chain AA (mean $=487 \mu M)$, total EAA $($ mean $=801 \mu M)$, total NEAA $($ mean $=1,025$ $\mu M)$, and total AA (mean $=1,826 \mu M)$, as well as the plasma Lys:Met ratio $($ mean $=3.62)$ did not differ $(P$ $\geq 0.13$ ) between diets (Table 4 ). The observed trend for increased plasma concentration of Val appeared to be an isolated effect because omasal flows of NANBN and total bacterial NAN were not changed (Table 3). Brito et al. (2008) reported that the plasma concentrations of Lys and Thr increased, whereas that of Met tended to increase in late-lactation dairy cows fed p.m.- versus a.m.-cut alfalfa baleage as the sole dietary ingredient. They also demonstrated that the plasma concentrations of most NEAA increased when feeding the p.m.cut alfalfa baleage (Brito et al., 2008). Contrarily, Brito et al. (2014) observed that the plasma concentrations of all individual EAA and most NEAA did not change in early-lactation dairy cows offered high- or low-NSC alfalfa baleage supplemented with concentrate, which generally agrees with the present results. Discrepancies in plasma AA concentration in response to diets containing forages with contrasting NSC concentrations are possibly explained by differences in DMI, MPS, milk yield, and dietary inclusion of concentrate.

\section{Intake and Milk Yield and Composition}

The effects of feeding the p.m.- versus the a.m.-cut TIM diet on production performance of 16 lactating dairy cows ( 8 ruminally cannulated) have been published (Brito et al., 2016). In the current paper, we reported DMI, milk yield, and milk composition from the 8 ruminally cannulated cows used for omasal sam- 
Table 4. Plasma concentration of AA in mid-lactation dairy cows fed diets containing p.m.-cut timothy baleage and silage (p.m.-cut TIM diet) or a.m.-cut timothy baleage and silage (a.m.-cut TIM diet) supplemented with a cracked corn-soybean meal-based concentrate mix

\begin{tabular}{|c|c|c|c|c|}
\hline \multirow[b]{2}{*}{ Item } & \multicolumn{2}{|c|}{ Diet } & \multirow[b]{2}{*}{ SEM } & \multirow[b]{2}{*}{$P$-value ${ }^{1}$} \\
\hline & p.m.-cut TIM & a.m.-cut TIM & & \\
\hline \multicolumn{5}{|l|}{$\mathrm{EAA}, \mu M$} \\
\hline His & 43.7 & 39.5 & 2.25 & 0.19 \\
\hline Ile & 123 & 119 & 7.49 & 0.39 \\
\hline Leu & 138 & 129 & 7.41 & 0.24 \\
\hline Lys & 74.1 & 72.1 & 3.82 & 0.64 \\
\hline Met & 20.0 & 20.9 & 1.22 & 0.52 \\
\hline Phe & 45.7 & 45.8 & 2.26 & 0.97 \\
\hline Thr & 93.5 & 95.9 & 7.12 & 0.66 \\
\hline Trp & 38.1 & 38.7 & 0.93 & 0.56 \\
\hline Val & 240 & 223 & 15.2 & 0.07 \\
\hline \multicolumn{5}{|l|}{ NEAA, $\mu M$} \\
\hline Ala & 190 & 204 & 8.68 & 0.18 \\
\hline Asn & 40.0 & 40.7 & 2.39 & 0.75 \\
\hline Asp & 21.1 & 23.4 & 1.30 & 0.19 \\
\hline Cys & 95.8 & 94.0 & 3.59 & 0.69 \\
\hline Gln & 265 & 281 & 12.9 & 0.27 \\
\hline Glu & 47.9 & 46.6 & 1.63 & 0.48 \\
\hline Gly & 173 & 186 & 7.46 & 0.19 \\
\hline Pro & 65.4 & 66.2 & 3.67 & 0.81 \\
\hline Ser & 58.8 & 59.1 & 3.94 & 0.93 \\
\hline Tyr & 45.2 & 46.8 & 3.31 & 0.70 \\
\hline \multicolumn{5}{|l|}{ Sum and ratio of $\mathrm{AA}$} \\
\hline Total branched-chain AA, $\mu M$ & 502 & 471 & 29.4 & 0.13 \\
\hline Total EAA, $\mu M$ & 817 & 784 & 36.7 & 0.31 \\
\hline Total NEAA, $\mu M$ & 1,002 & 1,048 & 27.7 & 0.17 \\
\hline Total AA, $\mu M$ & 1,819 & 1,832 & 58.3 & 0.81 \\
\hline Lys:Met ratio & 3.71 & 3.52 & 0.15 & 0.14 \\
\hline
\end{tabular}

${ }^{1}$ Probability of treatment effect (p.m.-TIM vs. a.m.-TIM diet); significance was declared at $P \leq 0.05$ and trends at $0.05<P \leq 0.10$.

pling and digesta flow measurements. Apart from milk lactose concentration, which was greater $(P=0.03)$ in cows fed the p.m.- than the a.m.-cut TIM diet (Table 5), no effect of diets $(P \geq 0.11)$ was detected for DMI, milk yield, and milk concentrations of fat, true protein, and MUN (Table 5). Yields of 4\% FCM and ECM increased

Table 5. Dry matter intake and milk yield and composition in mid-lactation dairy cows fed diets containing p.m.-cut timothy baleage and silage (p.m.-cut TIM diet) or a.m.-cut timothy baleage and silage (a.m.-cut TIM diet) supplemented with a cracked corn-soybean meal-based concentrate mix

\begin{tabular}{|c|c|c|c|c|}
\hline \multirow[b]{2}{*}{ Item } & \multicolumn{2}{|c|}{ Diet } & \multirow[b]{2}{*}{ SEM } & \multirow[b]{2}{*}{$P$-value ${ }^{1}$} \\
\hline & p.m.-cut TIM & a.m.-cut TIM & & \\
\hline$\overline{\mathrm{DMI}},{ }^{2} \mathrm{~kg} / \mathrm{d}$ & 18.0 & 17.3 & 0.68 & 0.17 \\
\hline Milk yield, $\mathrm{kg} / \mathrm{d}$ & 22.7 & 21.5 & 1.49 & 0.11 \\
\hline $4 \% \mathrm{FCM},{ }^{3} \mathrm{~kg} / \mathrm{d}$ & 22.8 & 21.5 & 1.64 & 0.05 \\
\hline $\mathrm{ECM},{ }^{4} \mathrm{~kg} / \mathrm{d}$ & 24.6 & 23.2 & $\begin{array}{l}1.04 \\
1.74\end{array}$ & 0.06 \\
\hline Milk fat, $\%$ & 4.02 & 4.04 & 0.21 & 0.79 \\
\hline Milk fat, $\mathrm{kg} / \mathrm{d}$ & 0.91 & 0.86 & 0.08 & 0.04 \\
\hline Milk true protein, $\%$ & 3.31 & 3.29 & 0.04 & 0.62 \\
\hline Milk true protein, $\mathrm{kg} / \mathrm{d}$ & 0.75 & 0.70 & 0.05 & 0.07 \\
\hline Milk lactose, $\%$ & 4.50 & 4.44 & 0.13 & 0.03 \\
\hline Milk lactose, $\mathrm{kg} / \mathrm{d}$ & 1.02 & 0.96 & 0.08 & 0.08 \\
\hline MUN, $\mathrm{mg} / \mathrm{dL}$ & 19.5 & 19.8 & 1.05 & 0.50 \\
\hline
\end{tabular}

${ }^{1}$ Probability of treatment effect (p.m.-cut TIM- vs. a.m.-cut TIM); significance was declared at $P \leq 0.05$ and trends at $0.05<P \leq 0.10$.

${ }^{2} \mathrm{DMI}$ presented in this table corresponds to measurements done from d 15 to 21 of each period.

${ }^{3} 4 \% \mathrm{FCM}=[0.40 \times$ milk yield $(\mathrm{kg} / \mathrm{d})]+[15 \times$ milk fat yield $(\mathrm{kg} / \mathrm{d})]($ Gaines and Davidson, 1923).

${ }^{4} \mathrm{ECM}=[0.327 \times$ milk yield $(\mathrm{kg} / \mathrm{d})]+[12.95 \times$ milk fat yield $(\mathrm{kg} / \mathrm{d})]+[7.2 \times$ milk true protein yield $(\mathrm{kg} / \mathrm{d})]$ (Orth, 1992). 
$(P \leq 0.06)$ in cows fed the p.m.- versus the a.m.-cut TIM diet (Table 5), which is in line with the observed increase $(P \leq 0.07)$ in milk fat and milk true protein yields (Table 5 ). These improvements in milk fat and milk true protein yields occurred primarily in response to increased NSC intake with feeding the p.m.-cut TIM $\operatorname{diet}$ (Table 1).

\section{CONCLUSIONS}

Feeding a TMR containing timothy baleage and silage with increased NSC concentrations (p.m.-cut TIM diet) did not affect MPS in the rumen and the omasal flow and plasma concentration of EAA. Increased $(+278 \mathrm{~g} / \mathrm{d})$ NSC intake and NSC digested in the rumen $(+316 \mathrm{~g} / \mathrm{d})$ in cows fed the p.m.-cut TIM diet were possibly too small to affect the omasal flows of bacterial NAN and EAA. Yields of milk fat and true protein increased in cows fed the p.m.-cut TIM diet, with these responses being primarily associated with enhanced NSC intake due to the lack of treatment effects on DMI, MPS, and omasal flow of EAA. The TMR fed in the present study contained (DM basis) 19\% of timothy silage and, because silage is more intensively fermented than baleage, this contributed to the small difference in NSC intake between the experimental diets. Therefore, future research should be focused exclusively on the effects of p.m.-cut timothy harvested as a drier forage (i.e., baleage, hay) on milk yield, ruminal MPS, and digesta flow of nutrients in lactating dairy cows.

\section{ACKNOWLEDGMENTS}

We thank Sylvie Provencher, Pamela Warburton, and Jocelyne Renaud for support during sample collection and laboratory analyses at the Dairy and Swine Research and Development Centre (Sherbrooke, QC, Canada). We further thank the assistance of Mario Laterrière and Josée Bourassa (Soils and Crops Research and Development Centre; Québec City, QC, Canada) for preparation and chemical analyses of forages used in our study. The statistical advice of Steve Méthot (Dairy and Swine Research and Development Centre) is gratefully appreciated. Authors also thank Keith Carter and the barn crew for excellent animal care and support during sampling (Dairy and Swine Research and Development Centre Farm), as well as the Normandin Research Farm crew for crop services (Normandin, QC, Canada). The financial support from Agriculture and Agri-Food Canada (Ottawa, ON, Canada) is acknowledged and appreciated. The authors have not stated any conflicts of interest.

\section{REFERENCES}

Ahvenjärvi, S., A. Vanhatalo, P. Huhtanen, and T. Varvikko. 2000 Determination of reticulo-rumen and whole-stomach digestion in lactating cows by omasal canal or duodenal sampling. Br. J. Nutr. 83:67-77. https://doi.org/10.1017/S0007114500000106.

Antaya, N. T., R. Berthiaume, G. F. Tremblay, and A. F. Brito. 2015. Short communication: Feeding red clover cut in the afternoon or morning to late-lactation dairy cows. J. Dairy Sci. 98:7335-7339. https://doi.org/10.3168/jds.2015-9333.

Berg, C. C., A. R. McElroy, and H. T. Kunelius. 1996. Timothy. Pages 643-664 in Cool-season forage grasses. L.E. Moser, D. R. Buxton, and M. D. Casler, ed. American Society of Agronomy, Crop Science Society of America, Soil Science Society of America.

Berthiaume, R. C. Benchaar, A. V. Chaves, G. F. Tremblay, Y. Castonguay, A. Bertrand, G. Bélanger, R. Michaud, C. Lafrenière, T. A. McAllister, and A. F. Brito. 2010. Effects of non-structural carbohydrate concentration in alfalfa on fermentation and microbial protein synthesis in continuous culture. J. Dairy Sci. 93:693-700. https://doi.org/10.3168/jds.2009-2399.

Bertrand, A., D. Prévost, F. J. Bigras, and Y. Castonguay. 2007. Elevated atmospheric $\mathrm{CO}_{2}$ and strain of rhizobium alter freezing tolerance and cold-induced molecular changes in alfalfa (Medicago sativa L.). Ann. Bot. 99:275-284. https://doi.org/10.1093/aob/ $\operatorname{mcl} 254$.

Bertrand, A., G. F. Tremblay, S. Pelletier, Y. Castonguay, and G. Bélanger. 2008. Yield and nutritive value of timothy as affected by temperature, photoperiod and time of harvest. Grass Forage Sci 63:421-432. https://doi.org/10.1111/j.1365-2494.2008.00649.x.

Blakeney, A. B., and L. L. Mutton. 1980. A simple colorimetric method for the determination of sugar in fruit and vegetables. J. Sci. Food Agric. 31:889-897. https://doi.org/10.1002/jsfa.2740310905.

Bowden, D. D., K. Taylor, and W. E. P. Davis. 1968. Water-soluble carbohydrates in orchardgrass and mixed forages. Can. J. Plant Sci. 48:9-15. https://doi.org/10.4141/cjps68-002.

Brito, A. F., G. F. Tremblay, A. Bertrand, Y. Castonguay, G. Bélanger, R. Michaud, C. Lafrenière, R. Martineau, and R. Berthiaume. 2014. Alfalfa baleage with increased concentration of nonstructural carbohydrates supplemented with a corn-based concentrate did not improve production and nitrogen utilization in early lactation dairy cows. J. Dairy Sci. 97:6970-6990. https://doi.org/ 10.3168/jds.2013-7305.

Brito, A. F., G. F. Tremblay, A. Bertrand, Y. Castonguay, G. Bélanger, R. Michaud, C. Lafrenière, R. Martineau, and R. Berthiaume. 2016. Performance and nitrogen use efficiency in mid-lactation dairy cows fed timothy cut in the afternoon or morning. J. Dairy Sci. 99:5445-5460. https://doi.org/10.3168/jds.2015-10597.

Brito, A. F., G. F. Tremblay, H. Lapierre, A. Bertrand, Y. Castonguay, G. Bélanger, R. Michaud, C. Benchaar, D. R. Ouellet, and R. Berthiaume. 2009. Alfalfa cut at sundown and harvested as baleage increases bacterial protein synthesis in late-lactation dairy cows. J. Dairy Sci. 92:1092-1107. https://doi.org/10.3168/jds.2008 -1469 .

Brito, A. F., G. F. Tremblay, A. Bertrand, Y. Castonguay, G. Bélanger, R. Michaud, H. Lapierre, C. Benchaar, H. V. Petit, D. R Ouellet, and R. Berthiaume. 2008. Alfalfa cut at sundown and harvested as baleage improves milk yield of late-lactation dairy cows. J. Dairy Sci. 91:3968-3982. https://doi.org/10.3168/jds.2008 $-1282$.

Broderick, G. A., P. Huhtanen, S. Ahvenjärvi, S. M. Reynal, and K. J. Shingfield. 2010. Quantifying ruminal nitrogen metabolism using the omasal sampling technique in cattle - A meta-analysis. J. Dairy Sci. 93:3216-3230. https://doi.org/10.3168/jds.2009-2989.

Canadian Council on Animal Care (CCAC). 1993. Guide to the Care and Use of Experimental Animals. Vol. 1. E. D. Olfert, B. M. Cross, and A. A. McWilliam, ed. CCAC.

Cochran, R. C., D. C. Adams, J. D. Wallace, and M. L. Galyean. 1986. Predicting digestibility of different diets with internal markers: Evaluation of four potential markers. J. Anim. Sci. 63:1476-1483. https://doi.org/10.2527/jas1986.6351476x. 
DuBois, M., K. A. Gilles, J. K. Hamilton, P. A. Rebers, and F. Smith. 1956. Colorimetric method for determination of sugars and related substances. Anal. Chem. 28:350-356. https://doi.org/10.1021/ ac60111a017.

France, J., and R. C. Siddons. 1986. Determination of digesta flow by continuous marker infusion. J. Theor. Biol. 121:105-119. https:// doi.org/10.1016/S0022-5193(86)80031-5.

Gaines, W. L., and F. A. Davidson. 1923. Relation between percentage fat content and yield of milk. Bull. 245. Illinois Agric. Exp. Sta., University of Illinois.

Hall, M. B. 2000. Neutral detergent-soluble carbohydrates: Nutritional relevance and analysis. A laboratory manual. Univ. Florida Ext. Bull. 339. Gainesville. Accessed Dec. 3, 2020. https://animal.ifas .ufl.edu/media/animalifasufledu/dairy/pdf/Manual_-_Neutral _Detergent-Soluble_Carbohydrates_Nutritional_Relevance_and Analysis.pdf.

Hall, M. B., W. H. Hoover, J. P. Jennings, and T. K. M. Webster. 1999. A method for partitioning neutral detergent soluble carbohydrates. J. Sci. Food Agric. 79:2079-2086. https://doi.org/10.1002/ (SICI) 1097-0010(199912)79:15<2079::AID-JSFA502>3.0.CO;2-Z.

Holm, J., I. Bjorck, A. Drews, and N. G. Asp. 1986. A rapid method for the analysis of starch. Stärke 38:224-226. https://doi.org/10 $.1002 /$ star.19860380704.

Huhtanen, P., P. G. Brotz, and L. D. Satter. 1997. Omasal sampling technique for assessing fermentative digestion in the forestomach of dairy cows. J. Anim. Sci. 75:1380-1392. https://doi.org/10 $.2527 / 1997.7551380 \mathrm{x}$.

Huhtanen, P., K. Kaustell, and S. Jaakkola. 1994. The use of internal markers to predict total digestibility and duodenal flow of nutrients in cattle given six different diets. Anim. Feed Sci. Technol. 48:211-227. https://doi.org/10.1016/0377-8401(94)90173-2.

Huntington, G. B., and J. C. Burns. 2007. Afternoon harvest increases readily fermentable carbohydrate concentration and voluntary intake of gamagrass and switchgrass baleage by beef steers. J. Anim. Sci. 85:276-284. https://doi.org/10.2527/jas.2006-370.

Johansen, M., A. L. F. Hellwing, P. Lund, and M. R. Weisbjerg. 2017. Metabolisable protein supply to lactating dairy cows increased with increasing dry matter concentration in grass-clover silage. Anim. Feed Sci. Technol. 227:95-106. https://doi.org/10.1016/j .anifeedsci.2017.02.018.

Karkalas, J. J. 1985. An improved enzymatic method for the determination of native and modified starch. J. Sci. Food Agric. 36:10191027. https://doi.org/10.1002/jsfa.2740361018.

Kokko, C., K. J. Soder, A. F. Brito, R. C. Hovey, and R. Berthiaume. 2013. Effect of time of cutting and maceration on nutrient flow, microbial protein synthesis, and digestibility in dual-flow continuous culture. J. Anim. Sci. 91:1765-1774. https://doi.org/10.2527/ jas.2011-4948.

Lechtenberg, V. L., D. A. Holt, and H. W. Youngberg. 1971. Diurnal variation in nonstructural carbohydrates in vitro digestibility, and leaf to stem ratio of alfalfa. Agron. J. 63:719-724. https://doi.org/ 10.2134/agronj1971.00021962006300050019x.

Lee, M. R. F., L. J. Harris, J. M. Moorby, M. O. Humphreys, M. K. Theodorou, J. C. MacRae, and N. D. Scollan. 2002. Rumen metabolism and nitrogen flow to the small intestine in steers offered Lolium perenne containing different levels of water-soluble carbohydrate. Anim. Sci. 74:587-596. https://doi.org/10.1017/ S1357729800052747.

Merry, R. J., M. R. F. Lee, D. R. Davies, R. J. Dewhurst, J. M. Moorby, N. D. Scollan, and M. K. Theodorou. 2006. Effects of high-sugar ryegrass silage and mixtures with red clover silage on ruminant digestion. 1. In vitro and in vivo studies of nitrogen utilization. J. Anim. Sci. 84:3049-3060. https://doi.org/10.2527/ jas.2005-735.
Morin, C., G. Bélanger, G. F. Tremblay, A. Bertrand, Y. Castonguay, R. Drapeau, R. Michaud, R. Berthiaume, and G. Allard. 2011. Diurnal variations of non-structural carbohydrates and nutritive value in alfalfa. Crop Sci. 51:1297-1306. https://doi.org/10.2135/ cropsci2010.07.0406.

Olmos Colmenero, J. J., and G. A. Broderick. 2006. Effect of dietary crude protein concentration on ruminal nitrogen metabolism in lactating dairy cow. J. Dairy Sci. 89:1694-1703. https://doi.org/10 .3168/jds.S0022-0302(06)72237-8.

Orth, R. 1992. Sample Day and Lactation Report. DHIA 200 FactSheet A-2. Mid-States Dairy Records Processing Center.

Pelletier, S., G. F. Tremblay, G. Bélanger, A. Bertrand, Y. Castonguay, D. Pageau, and R. Drapeau. 2010. Forage nonstructural carbohydrates and nutritive value as affected by time of cutting and species. Agron. J. 102:1388-1398. https://doi.org/10.2134/ agronj2010.0158.

Pelletier, S., G. F. Tremblay, C. Lafrenière, A. Bertrand, G. Bélanger, Y. Castonguay, and J. Rowsell. 2009. Nonstructural carbohydrate concentrations in timothy as affected by $\mathrm{N}$ fertilization, stage of development, and time of cutting. Agron. J. 101:1372-1380. https: //doi.org/10.2134/agronj2009.0125.

Reynal, S. M., and G. A. Broderick. 2005. Effect of dietary level of rumen-degraded protein on production and nitrogen metabolism in lactating dairy cows. J. Dairy Sci. 88:4045-4064. https://doi .org/10.3168/jds.S0022-0302(05)73090-3.

Reynal, S. M., G. A. Broderick, S. Ahvenjärvi, and P. Huhtanen. 2003. Effect of feeding protein supplements of differing degradability on omasal flow of microbial and undegraded protein. J. Dairy Sci. 86:1292-1305. https://doi.org/10.3168/jds.S0022-0302(03)73713 -8 .

Roman-Garcia, Y., R. R. White, and J. L. Firkins. 2016. Meta-analysis of post-ruminal microbial nitrogen flows in dairy cattle. I. Derivation of equations. J. Dairy Sci. 99:7918-7931. https://doi.org/10 .3168/jds.2015-10661.

Siddons, R. C., J. Paradine, D. E. Beever, and P. R. Cornell. 1985. Ytterbium acetate as a particulate-phase digesta-flow marker. Br. J. Nutr. 54:509-519. https://doi.org/10.1079/BJN19850136.

Simon, U., and B. H. Park. 1983. A descriptive scheme for stages of development in perennial forage grasses. Pages 416-418 in Proc. of the XIV Int. Grassland Congress, Lexington, KY. J. A. Smith and V. W. Hays, ed. Westview Press.

Titgemeyer, E. C. 1997. Design and interpretation of nutrient digestion studies. J. Anim. Sci. 75:2235-2247. https://doi.org/10.2527/ 1997.7582235x

Tremblay, G. F., C. Morin, G. Bélanger, A. Bertrand, Y. Castonguay, R. Berthiaume, and G. Allard. 2014. Silage fermentation of PMand AM-cut alfalfa wilted in wide and narrow swaths. Crop Sci. 54:439-452. https://doi.org/10.2135/cropsci2013.07.0443.

Udén, P., P. E. Colucci, and S. P. J. Van Soest. 1980. Investigation of chromium, cerium and cobalt as markers in digesta: Rate of passage studies. J. Sci. Food Agric. 31:625-632. https://doi.org/10 $.1002 /$ jsfa.2740310702.

Van Keulen, J., and B. A. Young. 1977. Evaluation of acid-insoluble ash as a natural marker in ruminant digestibility studies. J. Anim. Sci. 44:282-287. https://doi.org/10.2527/jas1977.442282x.

\section{ORCIDS}

A. F. Brito $\odot$ https://orcid.org/0000-0003-3209-5473

G. F. Tremblay @ https://orcid.org/0000-0001-7652-8985

R. Martineau (® https://orcid.org/0000-0002-6179-0080

R. Berthiaume ๑ https://orcid.org/0000-0002-7035-3675 